\title{
PENDAMPINGAN PEMASARAN ONLINE PADA KELOMPOK USAHA PENINGKATAN PENDAPATAN KELUARGA SEJAHTERA (UPPKS) DI KECAMATAN LOWOKWARU KOTA MALANG
}

\author{
Ida Nuraini $^{1}$, Dwi Susilowati ${ }^{2}$ \\ ${ }^{1,2}$ Universitas Muhammadiyah Malang \\ e-mail: nurainiida@yahoo.com
}

\begin{abstract}
The Covid 19 pandemic has an impact on the decline in sales of Micro, Small and Medium Enterprises (MSMEs) because most MSMEs cannot sell their products freely due to physical distancing policies and Large-Scale Social Restrictions. Meanwhile, many MSMEs have not been able to sell their products online because they do not have the skills to sell online. The purpose of this community service is training and online marketing assistance to the Business Group for Increasing Prosperous Family Income (UPPKS) in Lowokwaru District. The method of implementing activities is training to create business Instagram and Facebook accounts, techniques for taking photos of products, producing marketing videos, uploading product photos, tips on finding consumers, packaging techniques and product delivery. Partners are "atiqa" UPPKS members who produce handicrafts such as bags, wallets, tissue holders and mask. The result of the activity for 6 months was the joining of partners at the Shopee market place, active Instagram and business Facebook. Sales increase during the Covid 19 pandemic due to partners producing mask. The gross revenue from $1,500,000$ rupiah per month increases to 3,000,000-6,500,000 rupiah per month. Online sales can expand the marketing area, unlimited sales of time so as to increase sales.It is hope that other UPPKS members and MSMEs can sell online in order to increase revenue.
\end{abstract}

Keywords : Online marketing, Market place, Handicrafts

\section{PENDAHULUAN \\ Analisis Situasi}

Usaha Mikro Kecil Menengah di Indonesia merupakan salah satu bentuk usaha masyarakat yang mencerminkan ekonomi kerakyatan. Hal ini terbukti dari banyaknya jumlah pelaku Usaha Mikro Kecil Menengah (UMKM) yang menurut data Kementerian Koperasi, Usaha Kecil, dan Menengah (KUKM) tahun 2018 sebanyak 64,2 juta atau 99,99\% dari jumlah pelaku usaha di Indonesia. UMKM mampu menyerap tenaga kerja sebanyak 117 juta pekerja atau 97\% dari daya serap tenaga kerja dunia usaha. Sementara itu kontribusi UMKM terhadap perekonomian nasional (Produk Domestik Bruto) sebesar $61,1 \%$, dan sisanya yaitu $38,9 \%$ disumbangkan oleh pelaku usaha besar yang jumlahnya hanya sebesar 5.550 atau 0,01\% dari jumlah pelaku usaha. (Kementerian Keuangan RI, 2020). Namun dengan adanya COVID-19 UMKM mengalami masa-masa sulit dan bahkan tidak sedikit yang harus mengurangi tenaga kerja, penurunan penjualan bahkan menutup usahanya.Hasil survey BPS menyebutkan bahwa sebanyak 32,23\% Usaha Mikro Kecil mengurangi jumlah pekerjanya dan $82,85 \%$ jumlah usaha yang mengalami penurunan pendapatan. Beberapa sektor usaha yang penurunan pendapatannya sangat tinggi adalah sektor akomodasi dan makan minum, sektor jasa dan transportasi serta pergudangan.Dalam masa pandemic sebanyak 62,64\% usaha menggunakan internet untuk pemasarannya.(BPS, 2021)

Survei Kajian Cepat Dampak Pandemi COVID-19 terhadap Kinerja UMKM Indonesia yang dilakukan oleh Lembaga Pengetahuan Indonesia secara daring pada 1 20 Mei 2020 dan melibatkan 679 valid responden dengan mata pencaharian utama sebagai pelaku usaha.mengatakan bahwa selama pandemi, 94,69\% usaha mengalami penurunan penjualan. Berdasarkan metode penjualan, penurunan penjualan lebih dari $75 \%$ dialami oleh $47,44 \%$ usaha penjualan offline/fisik, 40,17\% usaha penjualan online, 
dan $39,41 \%$ usaha dengan metode penjualan offline sekaligus online. Berdasarkan skala usaha, penurunan penjualan lebih dari $75 \%$ dialami oleh $49,01 \%$ usaha ultra-mikro, 43,3\% usaha mikro, $40 \%$ usaha kecil, dan 45,83\% usaha menengah. (LIPI, 2020).

Pandemi covid 19 saat ini mengakibatkan banyak UMKM gulung tikar karena berbagai alasan seperti kesulitan bahan baku, kesulitan pemasaran dan kesulitan tenaga kerja. UMKM yang masih bertahan dan justru dapat meningkat penjualannya di saat pandemi covid 19 adalah yang kreatif dan pandai mengambil peluang seperti beralih metode penjualannya melalui online atau berpindah memproduksi barang-barang atau jasa yang berhubungan dengan covid 19 seperti masker, baju APD, makanan dan minuman herbal untuk meningkatkan imunitas tubuh, pelayanan makanan dan minuman secara delivery order, penyediaan jasa kurir dan sebagainya. korelasi antara strategi Pemasaran online sangat berpengaruh terhadap minat beli konsumen, sehingga pemasaran online merupakan strategi pemasaran yang sangat bermanfaat bagi para pelaku usaha. (Jati, Waluyo, Yuliansyah, 2017). Perkembangan teknologi dan respon masyarakat yang cepat terhadap kemajuan teknologi khususnya untuk pemasaran berdampak pada efektivitas dan efisiensi. Jangkauan pemasaran semakin luas tidak terbatas ruang dan waktu. (Maulidasari, 2020)

Kelompok Usaha Peningkatan Pendapatan Keluarga Sejahtera (UPPKS) merupakan kelompok usaha yang dilakukan oleh warga yang berada di bawah binaan kantor BKKBN. Kelompok ini terdiri dari warga yang sebagian besar ibu-ibu yang memiliki usaha kecil baik dalam bidang makanan, minuman, kerajinan tangan, pengolahan hasil pertanian, jasa dan sebagainya. Di setiap kelurahan memiliki puluhan binaan, salah satu mitra pengabdian adalah pelaku usaha kerajinan tangan yang tergabung dalam kelompok Usaha Peningkatan Pendapatan Keluarga Sejahtera (UPPKS) di Kecamatan Lowokwaru yaitu Ibu Nalin Kusuma yang memproduksi kerajinan tangan seperti tas, tempat tisu, bunga meja, tempat sisir, tempat kosmetik dan sebagainya. Produksi kerajinan tangan didasarkan atas pesanan yang diterima. terutama dari rekan atau kenalan sendiri. Penjualan masih dilakukan secara konvensional atau secara offline yaitu dengan mengikuti pameran, event-event yang dilakukan instansi dan acara-acara pertemuan, sehingga kegiatan produksi tidak bisa berlangsung setiap hari. Pemasaran melalui pameran dan event ini tidak bisa menjanjikan hasil penjualan yang banyak karena kegiatan tersebut tidak dilakukan secara rutin, apalagi pada masa pandemik covid 19 saat ini kegiatan pameran ataupun event tersebut tidak bisa dilaksanakan. Oleh karena itu dicari alternatif lain untuk meningkatkan omzet penjualan melalui pemasaran yang efektif. Pemasaran secara online yang telah dilakukan Mitra adalah melalui instagram tetapi belum efektif, terbukti jumlah pengikut Instagram selama 4 tahun hanya berjumlah 123 orang. Padahal pemasaran online harusnya dapat meningkatkan penjualannya, seperti hasil penelitian yang telah dilakukan oleh (Ambo Asse, 2018) yang menyimpulkan bahwa pemasaran secara online utamanya melalui facebook terbukti bermanfaat untuk penjualan, ia mengatakan bahwa tiga komponen utama facebook mampu menjalankan bauran pemasaran seperti periklanan, promosi penjualan dan penjualan langsung. Hal tersebut didukung pula oleh hasil penelitian (Sumarni, 2020) yang mengatakan bahwa pembuatan logo, stiker, akun google, akun WhatsApp Business, Instagram dan Akun Gofood. dapat meningkatkan penjualan warung Salapan pada saat pandemi Covid-19

Berdasar pengamatan pelaksana, ada beberapa kelemahan khususnya pada sistem pemasaran online yang digunakan oleh mitra yaitu Instagram dan facebook yang digunakan masih biasa belum menggunakan Instagram dan facebook bisnis. sehingga tidak banyak diikuti orang dan akhirnya produk yang diupload belum banyak dilihat orang, apalagi hashtag atau tagar yang dibuat kalimatnya tidak sesuai dengan kata kunci 
dari nama produk yang fotonya di upload dalam Instagram tersebut. Hal ini berdampak pada tidak ditemukannya produk mitra atau tidak munculnya foto produk mitra apabila orang mencari produk tersebut di situs online. Oleh sebab itu meskipun sudah menggunakan cara online dalam pemasarannya namun tidak banyak respon dari konsumen sehingga tidak banyak penjualan yang diperoleh dari cara online ini.

Mitra merasa kehabisan akal untuk menjual produknya ini karena baik berjualan dengan cara offline maupun online sangat sulit mendapatkan konsumennya. Karena itu penghasilan yang diterima oleh mitra sangat kecil dan tidak menunjukkan peningkatan selama 4 tahun menjalankan usahanya. Dari hasil wawancara yang telah dilaksanakan pelaksana dengan mitra diperoleh informasi bahwa omzet penjualan per bulan berkisar Rp 700.000,- hingga Rp. 1.500.000,-. Rendahnya omzet penjualan ini menjadi perhatian tim pelaksana untuk membantu meningkatkan omzet penjualannya melalui pelatihan dan pendampingan berjualan secara online yang sekarang lagi diminati oleh masyarakat apalagi saat pandemi covid 19 ini sangat efektif dan efisien dijalankan. Kurangnya pengetahuan Mitra dalam menggunakan akun Instagram maupun facebook seperti harus dilakukan migrasi ke akun Instagram bisnis, teknik membuat kalimat untuk hastag, teknik memfoto produk, cara membuat video pemasaran serta cara bergabung ke market place inilah yang perlu dilatih dan didampingi agar Mitra dapat berjualan online dengan benar dan tepat sehingga mampu meningkatkan penjualannya.

Berdasar evaluasi antara Mitra dan Tim pelaksana maka disepakati perlunya kegiatan pendampingan kepada Mitra agar dapat menjual produknya secara online baik melalui media sosial yang dimiliki maupun dengan cara bergabung ke market place. Oleh sebab itu tujuan kegiatan pendampingan adalah: 1) Mendampingi mitra merubah akun media sosialnya ke akun instagram, facebook dan whatsap bisnis serta teknik mengelolanya untuk menjual produk. 2) Mendampingi Mitra mendaftarkan usahanya ke salah satu market place yaitu Shopee.

\section{KAJIAN PUSTAKA}

\section{Konsep Pemasaran}

Pemasaran adalah suatu proses sosial dan manajerial dimana individu-individu dan kelompokkelompok memperoleh apa yang mereka butuhkan dan inginkan dengan menciptakan dan saling mempertukarkan produk dan jasa serta nilai antara seseorang dengan yang lainnya (Tanama Putri, 2017). Pendapat lain mengatakan bahwa inti pemikiran dan praktik pemasaran modern adalah memahami, menciptakan, mengkomunikasikan, dan memberikan nilai dan kepuasan kepada konsumen. Oleh karena itu, definisi singkat pemasaran adalah proses pemberian kepuasan kepada konsumen untuk mendapatkan laba (Sukamti, 2017).

Dari definsi tersebut dapat dijelaskan bahwa pemasaran merupakan fungsi bisnis yang mengidentifikasikan kinginan dan kebutuhan yang belum terpenuhi dan mengukur sberapa besar pasar atau pangsa pasar yang yang akan dilayani,mementukan pasar sasran yang akan dituju, menentukan berbagai produk, jasa dan program yag tepat untuk melayani pasar tersebut. Pemasaran juga merupakan proses social dan manajerial antara individu dan kelompok untuk mndapatkan apa yang mereka butuhkan dan inginkan maelalui penciptaan penawaran dan penukaraan nilai produk dengan yang lainnya. Dari konsep tersebut konsep pemasaran berkembang, tidak lagi sekedar sebagai fugsi untuk menentapkan produk apa yang cocok dipasar, tetapi berkembang menjadi lebih luas lagi dengan melibatkan individu dan kelompok. Pemasaran tidak hanya sekedar menjual produk tetapi yang lebih penting lagi adalah bagaimana interaksi sosial dengan konsumennya. Disamping itu factor lain yang menentukan keberhasilan pemasaran 
adalah factor harga. (Assauri S, 2011) dalam kesimpulan penelitiannya mengatakan bahwa harga merupakan satu-satunya unsur marketing mix yang menghasilkan penerimaan penjualan, sedangkan unsur lainnya hanya unsur biaya saja yang menentukan keberhasilan pemasaran. Untuk strategi pemasaran UMKM yang tepat dan sangat membantu peningkatan penjualan sebagaimana hasil penelitian terhadap usaha Batik Magenda Tamanan Kabupaten Bondowoso mengatakan bahwa strategi pemasarannya menerapkan atau menggunakan strategi bauran pemasaran atau yang lebih dikenal dengan istilah marketing mix dalam memasarkan produknya, yaitu melalui strategi produk, strategi harga, strategi tempat dan strategi promosi. Selain itu, strategi promosi yang dilakukan adalah dengan penjualan perorangan yaitu, bertatapan langsung dengan konsumen, pengiklanan yaitu kartu nama, dan media sosial seperti; Blog, Bbm, Facebook, Dan Whatsapp. menerapkan potongan harga, dan promosi dari mulut ke mulut. (Mandasari, 2019).

\section{Pemasaran Online}

Kemajuan dibidang teknologi telah mengubah segalanya, termasuk pemasaran. Konsep pemasaran yang berorientasi pada pemenuhan kebutuhan konsumen secara fisik sudah tergantikan secara non fisik. Dunia pemasaran bergeser secara virtual melalui system online, transaksi terjadi di dunia maya. Perkembangan pasar online sangat luar biasa. Media Sosial (medsos) sangat ampuh untuk melakukan pemasaran. Berdasarkan studi yang dilakukan terhadap UMKM di Bandung dalam hal penerapan strategi pemasaran. Secara umum UMKM terbagi kedalam dua cluster, pertama adalah industri kuliner, fashion, serta tour and travel. Pada industry ini strategi yang digunakan adalah dengan menekankan pada memberikan nilai tambah, diferensiasi produk dan layanan yang terbagi bagi pada para pelanggan mereka dibandingkan dengan para pesaingnya, dalam sisi harga, mereka juga memberikan harga yang kompetitif dan bersaing dibandingkan dengan kompetitor. Kedua, industri trading. Industri ini menggunakan strategi memberikan harga yang bersaing dan kompetitif dibandingkan dengan para pesaingnya untuk merebut pangsa pasar, selain itu mereka juga memiliki pasar sasaran yang cenderung mengarah pada niche market. Dalam hal penerapan teknologi, industri kuliner, fashion, serta tour and travel lebih banyak menggunakan website dan media sosial sebagai sarana untuk promosi yang efektif, berkomunikasi dengan para pelanggan, mengetahui pendapat dan mendapatkan saran dari pelanggan terhadap produk kita, serta dapat melakukan pengembangan produk sesuai dengan keinginan pasar. Sedangkan pada industri trading, lebih banyak membangun hubungan baik dengan jaringan distribusi mereka. (Dwija Utama, 2019). Dari hasil penelitian di atas dapat disimpulkan bahwa UMKM memiliki cara-cara tersendiri dalam penerapan teknologi digital saat ini, hal tersebut tentunya tergantung dari kemampuan UMKM dalam beradaptasi dengan teknologi terkini serta tergantung dari konsumennya masing-masing sektor industri.

Internet telah mengubah sifat dasar dari standar komunikasi pemasaran seperti periklanan dan promosi penjualan. Dalam hal ini, website serupa fungsinya dengan iklan dan merupakan media penjualan baru karena mampu memberikan informasi, bujukan, mengingatkan konsumen mengenai penawaran produk dan melakukan transaksi perdagangan elektronik (e-commerce). Suyanto dalam (Faisal, 2016) mengemukakan ecommerce merupakan konsep baru yang bisa digambarkan sebagai proses jual beli barang atau jasa pada world wide web Internet atau proses jual beli atau pertukaran produk, jasa dan informasi melalui jaringan informasi termasuk Internet. Dengan kata lain, website 
dianggap perpaduan antara periklanan dan penjualan langsung karena media ini juga dapat mengajak pengunjungnya dalam sebuah dialog atau interaksi langsung

Konsep pemasaran melalui media sosial seperti WhatsApp, Instagram, website, facebook disadari sangat ampuh dalam melakukan promosi. Model pemasaran seperti yang dilakukan oleh Shopee, Buka Lapak, Lazada dan Marketplace sangat membantu dalam meningkatkan penjualan terlebih dalam kondisi pandemic Covid 19. Lazada Indonesia mengakui Internet merupakan media yang potensial untuk mempertahankan konsumen dalam pemasaran online. Pemasaran elektronik adalah sisi perdagangan dari perdagangan elektronik, yang terdiri dari usaha perusahaan untuk mengkomunikasiskan, mempromosikan dan menjual barang dan jasa melalui Internet. Perbaikan desain atau bentuk serta peningkatan layanan konsumen yang dilakukan oleh website lazada Indonesia, akan mendorong kunjungan yang berkelanjutan oleh konsumen. Kunjungan berulang memberikan kesempatan untuk melakukan penjualan silang dan penjualan berulang melalui promosi penjualan yang ada di laman website lazada.co.id. Jelas, semua perusahaan harus mempertimbangkan untuk bergerak ke online (Philip, 2008). Tahapan lazada Indonesia dalam menjalankan pemasaran online melalui website antara lain: mendeskripsikan brand, produk, dan konsumen; menentukan dan merencanakan goals; merancang situs web yang efektif, merancang kegiatan promosi, memanfaatkan email untuk komunikasi dua arah, dan evaluasi

Pemasaran online saat ini merupakan salah satu pilihan yang tepat baik bagi konsumen maupun produsen karena akan lebih efektif dan efisien. Sebagaimana hasil penelitian yang dilakukan pada Distro Dlapak Street Wear yang menyimpulkan bahwa penjualan dengan e-commerce memiliki beberapa keuntungnan diantaranya yaitu dapat diakses dari mana saja dan kapan saja melalui jaringan internet, peningkatan efektifitas dan efisiensi, efektifitas proses penyampaian informasi produk tanpa terhalang oleh waktu dan tempat (Diki, 2017).

\section{METODE}

Kegiatan pendampingan penjualan secara online yang dilaksanakan Mitra dan Pelaksana dilakukan melalui beberapa tahapan seperti berikut:

\section{Tahap persiapan:}

Pada tahap persiapan, pelaksana bersama mitra mengidentifikasi karakteristik konsumen yang sudah membeli produk mitra beserta jenis produk yang paling banyak peminatnya atau produk yang memiliki peluang besar laku di pasar jika diproduksi. Kegiatan ini dimaksudkan untuk menentukan jenis media pemasaran online yang tepat dan jenis produk yang akan diluncurkan berikutnya. Mitra pengabdian diminta untuk membuat databased konsumen yang mencatat nama, alamat, nomor handphone/WA/FB/IG. Dengan adanya data based ini mitra akan lebih mudah untuk memberikan tawaran-tawaran atau melakukan promosi produknya. Setelah melakukan identifikasi, mitra diminta mempelajari market place shoope mulai dari persyaratan administrasi dan persyaratan teknis dan mekanisme kerjanya serta perlengkapan yang harus disiapkan.

\section{Tahap pelaksanaan:}

Pada tahap ini kegiatan yang dilakukan adalah pertama, pelaksana memberi pelatihan sekaligus pendampingan kepada mitra mengenai teknik memfoto produk/memproduksi video produk supaya hasil foto dan vidio menarik dan sesuai dengan standar yang disyaratkan oleh market place seperti Shopee. Kedua, Pelaksana memberi pelatihan dan pendampingan langkah-langkah membuat atau mengganti akun 
Instagram atau facebook biasa ke akun Instagram atau facebook binis serta strategi mendapatkan jumlah konsumen yang banyak. Ketiga, Mitra didampingi mendaftarkan tokonya ke market place Shopee. Keempat, Mitra dilatih cara menguplod foto/video produk ke akun IG/FB/Shoope sekaligus menanggapi pesanan, penyiapan produk dan packing sampai pengiriman dan penerimaan pembayarannya. Kelima, mitra dilatih membuat administrasi pemesanan dan pengiriman barang serta pembukuan keuangan usaha secara sederhana yang mencatat arus kas keluar dan masuk.

\section{Tahap evaluasi dan keberlanjutan:}

Pada tahap ini mitra dilatih dan didampingi membuat evaluasi usaha yang meliputi pencatatan penilaian produk oleh konsumen di market place/IG/FB dan selalu mencatan peringkat bintang toko mitra. Mitra harus dapat menyimpulkan hal apa saja yang menjadi hambatan-hambatan serta hal apa saja yang menjadi pendorong penjualan produknya dan kemudian mitra didampingi membuat strategi berikutnya agar penjualan semakin meningkat.

\section{HASIL KARYA UTAMA DAN PEMBAHASAN}

\section{A. Karakteristik Konsumen Mitra Pengabdian}

Pada kegiatan identifikasi karakteristik konsumen yang dilakukan mitra bersama pelaksana diperoleh gambaran bahwa sejak tahun 2015 hingga awal tahun 2020 sebagian besar konsumen berasal dari daerah Malang Raya dan merupakan teman atau orang-orang yang sudah kenal dengan Mitra. Produk yang diminati oleh konsumen adalah tas (sling bag) dan dompet. Harga tas berkisar antara Rp.100.000,- hingga Rp. 500.000, dan yang sering dipesan konsumen adalah tas yang harganya sekitar Rp. 150.000,- sementara harga jual dompet berkisar antara Rp. 50.000,- hingga Rp. 150.000,- , dan yang banyak permintaannya adalah yang harga Rp.100.000,- Produk lain seperti tempat tisu, sarung bantal dan tempat pensil juga ada yang memesannya namun tidak sebanyak tas dan dompet. Pemesanan konsumen banyak berasal dari kegiatan pameran yang diikuti oleh Mitra baik yang diselenggarakan oleh instansi pemerintah maupun swasta. Pemesanan melalui Instagram hanya beberapa saja dan itupun dari teman atau kenalan. Pemesanan melalui Instagram tidak menunjukkan perkembangan yang berarti hal ini menurut pengamatan pelaksana disebabkan oleh belum digunakannya Instagram bisnis oleh Mitra dan tidak digunakannya hastag yang tepat sehingga produk mitra tidak bisa muncul di menu pencarian baik yang ada di google maupun yahoo. Mitra juga tidak memberikan ulasan spesifikasi produk beserta harganya, sehingga calon pembeli tidak bisa mengetahui secara detail produk Mitra. Selain itu Mitra belum dapat menampilkan foto yang baik yang membuat orang tertarik apabila melihat foto produk Mitra.

\section{B. Hasil Kegiatan}

Sejak tahun 2015 hingga tahun 2020 usaha yang dijalankan mitra belum menunjukkan perkembangan yang sangat berarti. Hal itu bisa dilihat dari belum ada penambahan dalam omzet penjualan, asset usaha maupun tenaga kerja. Semua kegiatan operasional masih bisa dikerjakan sendiri oleh Mitra. Pencatatan usaha juga belum dilakukan sehingga tidak bisa diketahui dengan pasti keuntungan usaha Mitra, namun berdasar perkiraan Mitra, omzet penjualan rata-rata sebesar Rp.1.500.000,- per bulan dan belum bisa diketahui berapa penghasilan bersihnya.

Mulai bulan Maret hingga Oktober 2020 pelaksana memberi pelatihan dan pendampingan kepada mitra mengenai teknik berjualan online baik melalui Instagram, Facebook dan Market Place. Tahap pertama dimulai dari pelatihan teknik memfoto produk dan teknik mengupload foto produk. Hasil yang diperoleh adalah Mitra dapat 
memfoto produknya dengan baik sesuai ketentuan yang disyaratkan oleh marketplace khususnya shopee. Di bawah ini adalah contoh hasil foto Mitra sebelum diberi pelatihan.

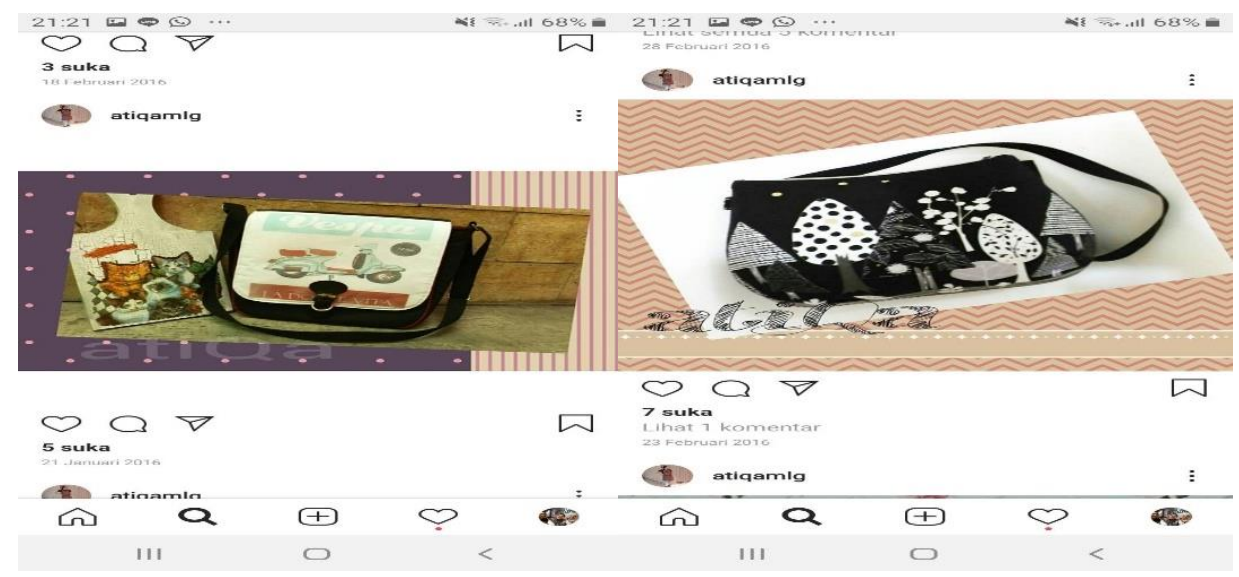

Gambar 1: Instagram Mitra Sebelum Pelatihan

Foto di Instagram Mitra seperti gambar diatas belum memenuhi standar yang disyaratkan oleh marketplace. Background yang digunakan masih warna-warni sehingga kelihatan rame dan membuat produk semakin tidak kelihatan. Cara meletakkan posisi produk saat di foto juga belum betul yang harusnya berdiri dan yang dilakukan mitra dengan cara menidurkan produk. Hal-hal kecil dalam teknik foto belum dipahami mitra sehingga foto mitra terkesan asal-asalan dan tidak mengandung seni pemasaran. Hal ini dapat berakibat pada rendahnya daya tarik konsumen terhadap produk Mitra.

Instagram mitra juga masih merupakan Instagram biasa bukan instagram bisnis. Pada Instagram ini tidak ada deskripsi produk secara rinci seperti ukuran, bahan dan harga serta alamat atau contact Person Mitra, apalagi kalimat hashtag tidak ada sama sekali sehingga tidak akan muncul di mesin pencarian google ataupun yahoo apabila ada orang atau calon konsumen mencari produk di internet. Dengan dilatihnya Mitra dalam mengelola Instagram, maka Mitra telah dapat memfoto produknya dengan hasil yang menarik serta dapat mengunggah foto produk tersebut dengan menambahkan deskripsi produk serta informasi lain seperti nomor contact person Mitra untuk pemesanan produk. Di bawah ini tampilan Instagram Mitra setelah Mitra diberi pelatihan dan pendampingan.
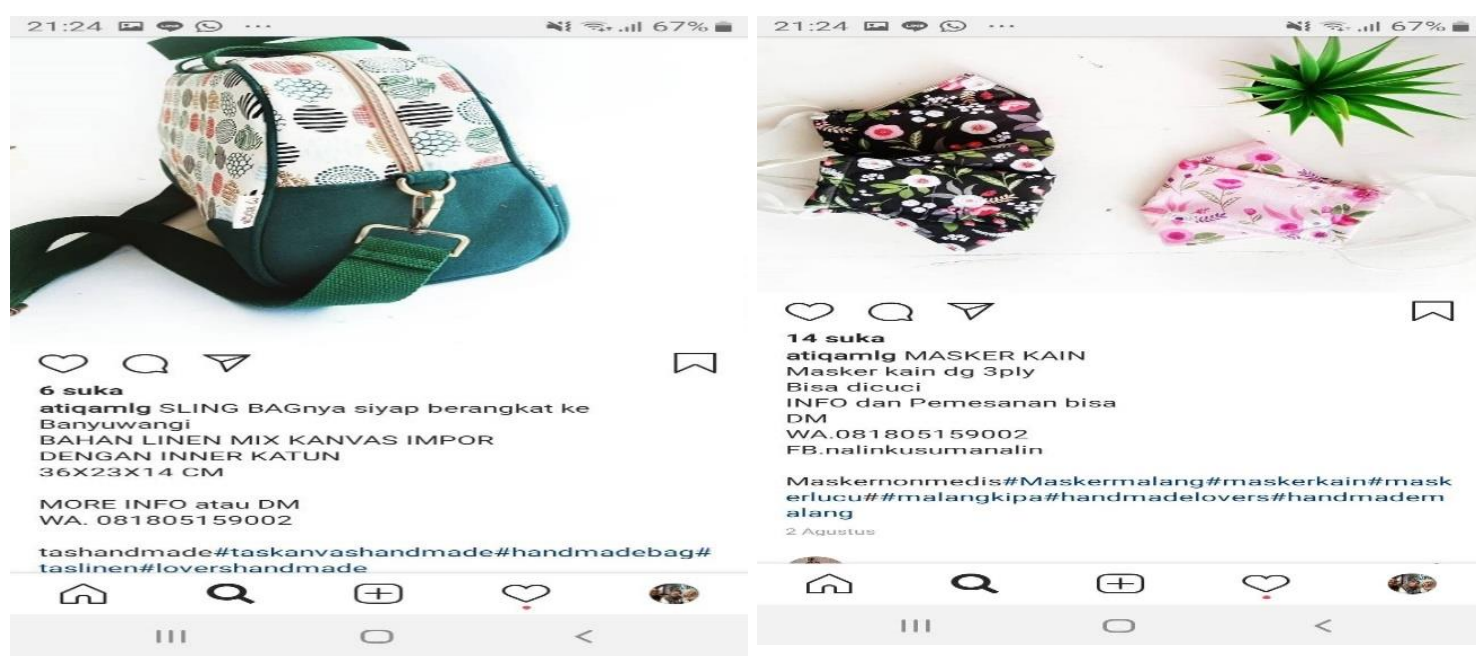


\section{Gambar 2 : Instagram Mitra Setelah Pelatihan}

Tampilan Instagram Mitra sudah berubah setelah berpindah ke Instagram bisnis. Instagram sudah menampilkan deskripsi produk dan informasi pemesanan produk, hashtag sudah fokus pada kata kunci sehingga apabila calon konsumen mencari produk pada mesin pencarian seperti google dan yahoo maka produk Mitra akan muncul. Semenjak dituliskan nomor contact person Mitra di setiap produk yang diunggah pada Instagram Mitra mulai mendapatkan banyak pesanan produk dari konsumen yang berasal dari luar kota Malang dan khususnya untuk produk masker yang sengaja diproduksi saat pandemic virus covid 19. Produk masker merupakan produk yang paling diminati oleh konsumen dan sangat membantu mitra khususnya saat pandemic covid 19 yang hampir semua usaha mengalami kerugian, namun mitra justru menerima banyak pesanan masker.

Pelatihan lain yang diberikan kepada mitra adalah pelatihan bergabung di market place Shopee dengan nama toko Atiqahandmade. Dengan bergabungnya mitra ke Shopee mitra dapat menjual produknya dalam jangkauan yang lebih luas. Tampilan produk Mitra di market place adalah sebagai berikut:

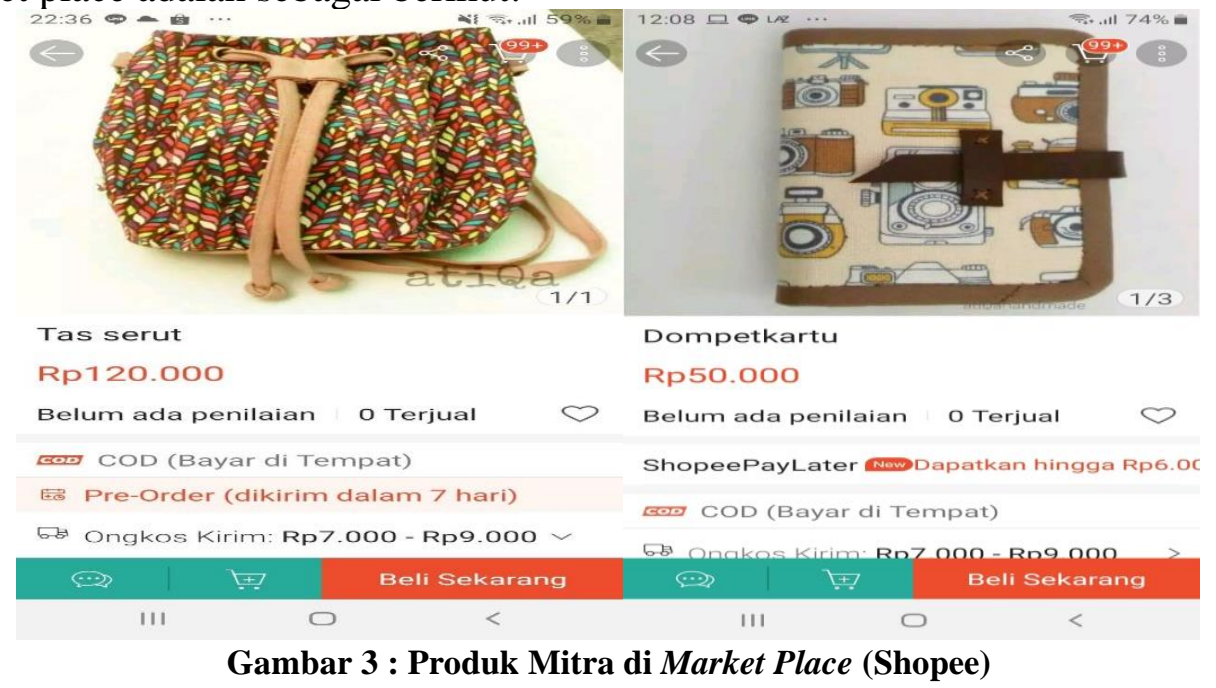

Bergabungnya Mitra di market place Shopee juga berdampak positif pada meningkatnya permintaan produk Mitra khususnya masker. Permintaan sebagian besar berasal dari wilayah Jakarta kemudian Surabaya dan Malang Raya. Ada pula yang berasal dari Kalimantan namun tidak terlalu banyak. Omzet penjualan Mitra naik dari rata-rata Rp.1.500.000,- per bulan menjadi berkisar Rp.3.000.000,- Rp.6.500.000,- atau rata-rata per bulan sebesar Rp. 5.500.000,-. Pandemi covid 19 memberikan dampak pada peningkatan permintaan produk Mitra berupa masker, sehingga dapat memberikan penghasilan bersih Mitra sebesar Rp.1.500.000,- Hal ini merupakan prestasi yang besar karena jika sebelum pelatihan penghasilan Rp.1.500.000,- tersebut merupakan penghasilan kotor atau omzet penjualan dan setelah pelatihan angka tersebut merupakan penghasilan bersih. Selama dilakukannya pendampingan Mitra telah dapat menyisihkan penghasilannya untuk menambah 1 unit mesin jahit baru seharga Rp.3.500.000,-. Berikut mesin jahit yang berhasil dibeli oleh Mitra dengan sebagian uang yang disisihkan dari penghasilan usahanya selama bulan April hingga Oktober 2020. 


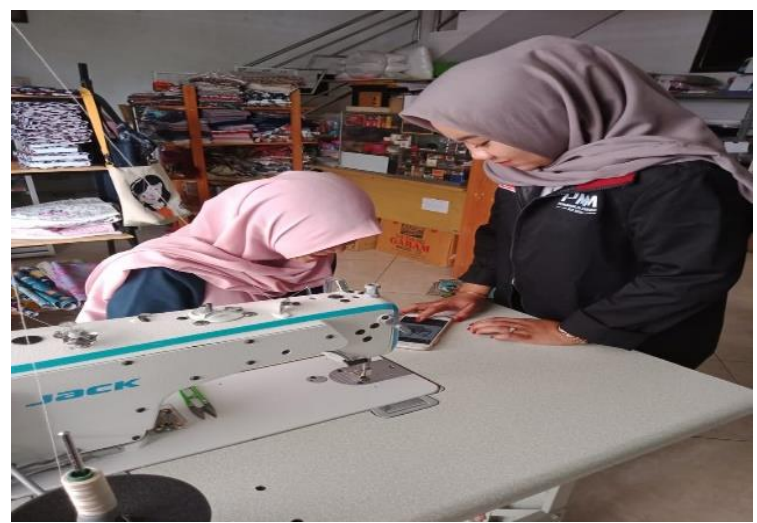

Gambar 4 : Mesin Jahit Baru Hasil Keuntungan Usaha

Dengan dimilikinya mesin jahit baru ini Mitra saat ini sudah dapat menambah satu orang karyawan yang bertugas menjahit agar dapat memenuhi permintaan produk masker dari para pemesan. Diharapkan ke depan produk Mitra terus bertambah baik jenis maupun jumlahnya. Mitra juga diharapkan dapat mengajarkan ketrampilan berjualan online kepada anggota UPPKS yang lain.

Kegiatan terakhir yang dilaksanakan oleh Mitra dengan pendampingan pelaksana adalah melakukan evaluasi atas kinerja usaha Mitra. Mitra didampingi dalam mengevaluasi terhadap keberhasilan dan hambatan yang terjadi selama menjalankan usaha online. Mitra harus dapat mengidentifikasi faktor-faktor penunjang dan penghambat keberhasilan. Hal yang bisa dicatat Mitra atas keberhasilannya adalah perlunya menangkap peluang usaha produk baru yang sesuai dengan kebutuhan konsumen saat ini seperti masker. Masker yang diproduksi juga harus selalu memperhatikan target pasar seperti masker untuk anak, masker untuk hijab, masker untuk laki-laki dan masker untuk kantor atau instansi berdasar pesanan dengan motif dan tulisan tertentu. Kendala yang dihadapi sebelum adanya tambahan karyawan adalah pesanan yang diterima umumnya minta segera dikirim dan jika jumlahnya banyak atau bersamaan berakibat pada tertundanya pengiriman. Dengan adanya tambahan karyawan saat ini belum ada masalah pengiriman yang tertunda. Catatan penting lain adalah Mitra harus sering mengecek handphone setiap saat karena pesanan yang masuk bisa sewaktu-waktu, jika tidak sering di cek pesanan online akan berakibat pada lambatnya Mitra merespon pesanan yang masuk secara online. Untuk keberlanjutan usaha, Mitra sudah melakukan saving yang digunakan untuk berjaga-jaga jika sewaktu-waktu diperlukan yang terkait dengan kebutuhan operasional usahanya.

\section{PEMBAHASAN}

Kegiatan pengabdian yang dilaksanakan berupa pendampingan pemasaran online kepada Mitra dimulai dari evaluasi karakteristik konsumen Mitra yang mana sebagian besar adalah teman sendiri, untuk itu diperlukan perluasan calon konsumen yaitu seluruh masyarakat di Indonesia melalui pemasaran online. Untuk itu tahapan pendampingan yang berikutnya adalah merubah akun Instagram dan facebook biasa menjadi Instagram dan facebook bisnis dan telah menunjukkan keberhasilan diantaranya adalah peningkatan folowers Mitra, peningkatan ketrampilan mitra dalam teknik foto produk, Teknik membuat hashtag dan mendeskripsikan produk, hal ini penting karena dapat berpengaruh pada jangkauan dan kemudahan konsumen menemukan produk yang diupload oleh Mitra. Perubahan akun ini menuntut Mitra untuk lebih aktif dalam menggunakan media sosial yang dimiliki khususnya dalam mengupload produk-produk baru khususnya masker yang saat ini permintaannya masih tinggi dari masyarakat. Mitra dituntut selalu aktif menanggapi pertanyaan-pertanyaan dari calon konsumen yang menanyakan terkait 
produk yang akan di pesan. Pemasaran online ini menjadikan konsumen sewaktu-waktu dapat memesan produk kepada Mitra, sehingga Mitra harus selalu aktif setiap saat melihat dan membaca pesan-pesan yang diterimanya secara online. Mitra harus mampu meluangkan waktu untuk menanggapi pesan-pesan dari calon pembeli.

Pemasaran online juga membawa konsekuensi Mitra untuk meningkatkan kreativitasnya khususnya dalam desain produk-produk sesuai yang diinginkan konsumen. Peningkatan penjualan Mitra salah satunya disebabkan oleh kreativitas Mitra yang mampu memanfaatkan situasi COVID 19 dengan menambah produknya yang semula fokus pada tas dan dompet kemudian menambah produknya yaitu Masker.

Mitra didampingi dalam mengevaluasi terhadap keberhasilan dan hambatan yang terjadi selama menjalankan usaha online. Mitra harus dapat mengidentifikasi faktorfaktor penunjang dan penghambat keberhasilan. Hal yang bisa dicatat Mitra atas keberhasilannya adalah perlunya menangkap peluang usaha produk baru yang sesuai dengan kebutuhan konsumen saat ini seperti masker. Adapun kendala yang dihadapi oleh Mitra dapat dijelaskan sebagai berikut :

1. Keterbatasan Design untuk di upload di media sosial

Untuk mengikuti perkembangan /trend mode maka produk harus sering di up date. Untuk melakukam up date foto di media sosial Mitra kesulitan karena keterbatasan pengetahuan dan pengalaman Mitra dalam tehnik penampilan foto yang menarik. Mitra sangat tergantung pada permintaaan konsumen dengan cara mengirim foto/model/gambar yang diinginkan. Sebagai solusi Mitra harus kreatif dan punya inisiataf untuk selalu membuat model baru mengikuti perkembangan sehingga tidak tergantung pada model yang diberikan konsumen.

2. Keterbatasan pembuatan produk

Startegi pemasaran online yang dijalankan oleh Mitra berdampak pada peningkatan permintaaan produk terutama untuk permintaaan masker dan tas. Hampir semua konsumen meminta produk dibuat secepatnya dan dikirim secepatnya. Padahal untuk membuat produk terutama tas harus terlebih dahuku menyiapkan model dan pola terlebih dahulu. Bahan pembuatan produk tidak selalu tersedia di daerah Malang dan harus di beli dari Jakarta sehingga memerlukan waktu yang cukup karena bahannya termasuk bahan impor. Untuk produk masker tidak masalah karena tidak memerlukan model yang rumit. Permintaaan yang banyak dan tidak dikuti dengan kemampuan untuk meningkatk produksi karena ketrebtasan tenaga kerja, berakibat pada tertundanya pengiriman barang ke konsumen. Kondisi ini tentu kurang menguntungkan dan dalam jangka panjang sangat merugikan karena dapat kehilangan peluang penjualan produk dan kehiangan konsumen.

Sebagai solusi dalam permasalahan tersebut, maka tim pengabdi menyarakan untuk merekut tenaga kerja 1 orang untuk membantu proses produksi. Selama ini produksi dikerjakan sendiri karena keterbatasan modal. Tambahan tenaga kerja sebanyak satu orang akan sangat membantu sekali dalam meningkat produksi khususnya produk masker. Kondisi memunginkan dengan dukungan tambahan mesin jahit yang baru. Dengan tambahan karyawan saat maka masalah pengiriman yang tertunda dapat teratasi

3. Lambatnya Respon Mitra

Pesanan yang masuk secara online sangat lambat direspon oleh Mitra karena keterbatasan Mitra untuk selalu cek handphone padahal Mitra harus sering mengecek handphone setiap saat karena pesanan yang masuk bisa sewaktu-waktu. Selain itu Handphone yang dimiliki Nitra juga sudah tidak up todate lagi dan harus diganti yang lebih bagus lagi. Khusus suntuk kepemilikan handphone seharus 2 (dua) buah satu khusus untuk melayani bisnis dan satunya lagi khusus untuk pribadi biar tidak campur.

Sebagia solusi adalah Mitra disarankan untuk membeli handphone lagi dan untuk selalu stand by dengan orderan yang setiap saat masuk secara on line 
Untuk keberlanjutan usaha, Mitra sudah melakukan saving yang digunakan untuk berjaga-jaga jika sewaktu-waktu diperlukan yang terkait dengan kebutuhan operasional usahanya.

Tantangan yang dihadapi Mitra saat ini dan dimasa yang akan datang setelah memasuki pasar on;ine adalah dalah semakin berate karena tingginya persaingan baik di dalam negeri maupun di luar negeri menuntut Mitra untuk selalu kreatif menghasilkan produk yang bisa bersaing di pasar.

Selain pemasaran online Mitra juga harus tetap melakukan pasar off line seperti mengikuti event-event atau pameran yang diadakan instansi Pemerintah maupun swasta uantuk menjaga keberlanjutan Usahanya. Sejalan dengan hasil penelitian (Rokhmah, 2020) mengenai tantangan dan kendala pemasaran online UMKM yang menyimpulkan bahwa dengan pasar online persaingan tidak hanya dari dalam negeri tetapi juga dari luar negeri.

\section{KESIMPULAN}

Setelah dilakukan pengabdian dalam bentuk pendampingan selama kurang lebih 6 bulan dapat di simpulkan sebagai berikut, kegiatan pendampingan yang dimulai dengan pendampingan memindahkan akun Instagram dan facebook biasa menjadi akun Instagram dan facebook bisnis telah berhasil dilakukan Mitra dan berhasil meningkatkan jumlah followers, meningkatkan ketrampilan Mitra dalam mengelola akun Instagram dan facebook bisnis seperti trampil dalam teknik foto, mendeskripsikan produk dan membuat hashtag pada Instagram yang berdampak pada makin meningkatnya jumlah pesanan produk handmade seperti tas, dompet dan masker.

Disamping media sosial Instagram dan facebook Mitra didampingi mendaftarkan tokonya ke market place yaitu Shopee. Setelah punya toko di Shopee permintaan konsumen datang tidak hanya dari kota Malang tetapi dari berbagai wilayah seperti Jakarta, Surabaya, Kalimantan dan Malang Raya, khususnya permintaan produk Masker dan Tas. Permintaan Masker meningkat tajam seiring dengan meningkatnya kasus COVID 19 di berbagai Kota. Dampak yang signifikan dari penjualan online yaitu meningkatnya rata-rata pendapatan kotor Mitra dari Rp.1.500.000,- menjadi Rp.5.500.000,-. per bulan

Disarankan kepada Mitra agar aktif dengan media sosial dan setiap saat untuk melihat pesanan yang masuk khususnya di market place Shopee agar tidak terlambat menyiapkan pesanan konsumen karena jika terlambat mengirim pesanan akan berdampak pada menurunnya performa toko yang bisa dilihat dari penilaian konsumen terhadap toko. Untuk UMKM lain yang belum memiliki pemasaran secara online disarankan agar memiliki pemasaran online karena situasi COVID 19 yang belum diketahui kapan berakhir sangat efektif jika usaha yang dijalankan melakukan pemasaran secara online.

\section{UCAPAN TERIMAKASIH.}

Ucapan terima kasih Tim Pengabdian Kepada Masyarakat kepada Fakultas Ekonomi Ekonomi dan Bisnis Universitas Muhammadiyah Malang yang telah mensupport moril maupun fasilitas dan segala kebutuhan Tim Pengabdian kepada masyarakat dalam melaksanakan pengabdian kepada masyarakat ini. Ucapan terimaksih juga disampaikan kepada Kelompok Usaha Peningkatan Pendapatan Keluarga Sejahtera (UPPKS) Kecamatan Lowokwaru yang telah bersedia mengikuti pendampingan pengabdian masyarakat dan khususnya kepada Ibu Nalin Kusuma selaku Pemilik usaha yang telah berkenan menjadi Mitra pengabdian. Terimakasih juga kepada mahasiswa yang tergabung dalam Tim Pengabdian Masyarakat Mitra Dosen yang telah membantu dalam memproduksi content berita, video dan foto-foto di media social. 


\section{DAFTAR PUSTAKA}

Ambo Asse, R. A. (2018). Strategi Pemasaran Online (Studi Kasus Facebook Marketing Warunk Bakso Mas Cingkrank di Makasar). Jurnal Komunikasi KAREBA, Vol. 7 Assauri S. (2011). Manajemen Pemasaran. PT. Raja Grafindo Persada.

BPS. (2021). Analisis Hasil Survei Dampak Covid-19 terhadap Pelaku Usaha.

Diki, S. (2017). Sistem Penjualan Berbasis E-Commerce Menggunakan Metode Objek Oriented pada Distro Dlapak Street Wear. Jurnal Sistem Informasi, 4 Hal 5-8.

Dwija Utama, I. (2019). Analisis Pemasaran Pada Usaha Mikro Kecil dan Menengah (UMKM) Pada Era Digital di kota Bandung. Equilibrium, Jurnal Ilmiah Ekonomi Dan Pembelajarannya, Volume 7

Faisal, R. (2016). Strategi Promosi Penjualan Online Lazada.Co.Id, PT. Bank Mandiri (Persero) Tbk. Jurnal Kajian Komunikasi, Volume 4

Jati, Waluyo, Yuliansyah, H. (2017). Pengaruh Strategi Pemasaran Online (Online Marketing Strategy) Terhadap Minat Beli Konsumen (Studi Kasus pada online Shop Azzam Store). Jurnal Pemasaran Kompetitif, Vol.1 nomor 1.

Kementerian Keuangan RI. (2020). UMKM Bangkit, Ekonomi Indonesia Terungkit. https://www.djkn.kemenkeu.go.id/

LIPI. (2020). Survei Kinerja UMKM di Masa Pandemi Covid 19.

Mandasari, D. J. dkk. (2019). Strategi Pemasaran Usaha Mikro Kecil dan Menengah (UMKM) Batik Magenda Tamanan Kabupaten Bondowoso. Jurnal Pendidikan Ekonomi: Jurnal Ilmiah Ilmu Pendidikan, Ilmu Ekonomi Dan Ilmu Sosial, Volume 13.

Maulidasari, C. D. (2020). Dampak Pemasaran Online di Era Covid-19. Jurnal Bisnis Dan Kajian Strategi Manajemen, 4 Nomor 2.

Philip, K. \& A. G. (2008). Prinsip-prinsip Pemasaran. Erlangga, Jakarta.

Rokhmah, B. E. (2020). TANTANGAN, KENDALA, DAN KESIAPAN PEMASARAN ONLINE UMKM DI DESA NGLEBAK, KECAMATAN TAWANGMANGU, KABUPATEN KARANGANYAR. Filantropy Jurnal Manajemen Zakat Dan Wakaf, Volume 1

Sukamti. (2017). Konsep Pemasaran dan Proses Manajemen Pemasaran. https://www.pustaka.ut.ac.id/

Sumarni, T. (2020). Media Sosial dan e-commerce sebagai Solusi Tantangan Pemasaran Pada Masa Pandemi Covid-19 (Studi kasus : UMKM Warung Salapan. ATRABIS: Jurnal Administrasi Bisnis, Vol. 6

Tanama Putri, B. R. (2017). Manajemen Pemasaran. https://simdos.unud.ac.id/ 